\title{
Dental pathology in dolphins (Cetacea: Delphinidae) from the southern coast of Brazil
}

\author{
Carolina Loch ${ }^{1,3,4, *}$, Liliane J. Grando ${ }^{2}$, Jules A. Kieser ${ }^{3}$, Paulo C. Simões-Lopes ${ }^{1}$ \\ ${ }^{1}$ Laboratório de Mamíferos Aquáticos, Departamento de Ecologia e Zoologia and ${ }^{2}$ Departamento de Patologia, \\ Centro de Ciências da Saúde, Universidade Federal de Santa Catarina, 88040-970, Florianópolis, Santa Catarina, Brazil \\ ${ }^{3}$ Sir John Walsh Research Institute, Faculty of Dentistry, University of Otago, Dunedin 9054, Otago, New Zealand \\ ${ }^{4}$ Present address: Department of Geology, University of Otago, Dunedin 9054, Otago, New Zealand
}

\begin{abstract}
Pathological processes observed in the stomatognathic systems of mammalian species are a useful source of information about the habits, evolution and general health of such animals. Studies of pathological conditions on teeth are common in humans and other primates, but rare in wild animals in general and marine mammals in particular. For cetaceans, previous studies provided scanty records of dental anomalies in a few species. This is the first broad and systematic inventory of dental pathology in dolphins. Specimens stored at scientific collections from the southern coast of Brazil were visually inspected under a stereoscopic microscope using a dental explorer. Diagnosis of lesions and anomalies followed literature descriptions. Abnormalities such as caries-like lesions, mineralized calculus deposits, dental erosion, enamel anomalies (hypoplasia and exogenous pigmentation), root resorption, germination and other shape anomalies, were diagnosed in the delphinids Sotalia guianensis, Delphinus capensis, Stenella frontalis, Stenella coeruleoalba, Lagenodelphis hosei, Pseudorca crassidens, Orcinus orca, Steno bredanensis and Tursiops truncatus. Endogenous causes may be related to the occurrence of certain conditions, but the aetiology of caries-like lesions and calculus accumulation is still unknown for cetaceans. The diagnosis of alveolar anomalies and other bone lesions in specimens with dental pathology lead us to believe these lesions modify the integrity of the periodontal ligament and bony tissues, adding to the burden of morbidity of affected animals.
\end{abstract}

KEY WORDS: Caries-like lesions $\cdot$ Dental calculus $\cdot$ Erosion $\cdot$ Geminated teeth $\cdot$ Marine mammals Resale or republication not permitted without written consent of the publisher

\section{INTRODUCTION}

Teeth form a prominent part of mammal remains in palaeontological and archaeological sites because of their tough composition, and together with skeletal remains they have much to contribute to the study of ecology, functional morphology and systematics of fossil and recent species (Bergqvist 2003). Few morbid conditions affect the teeth and skeleton in a way that leaves visible changes in the hard material, with pathological phenomena generally being restricted to soft tissues. In spite of this limitation, the study of the pathology of hard tissues can broaden our understanding of diseases and their role in animal biology, as well as their interactions with the environment (Ortner \& Putschar 1981).
Studies of normal and pathological dental conditions are of major importance in phylogenetic reconstruction, evaluation of stress and deprivation during growth and development, and in the assessment exposure to pathogens or injury. Descriptions of pathology of the orodental complex in humans and other mammals have ranged from reports and case studies to analyses that emphasize biofunctional perspectives of these diseases in relation to behavioural, archaeological, evolutionary and environmental circumstances (Larsen 1997). Moreover, variation in dental morphology has been a critical source of information for the interpretation of dietary behavior and phylogenetic relationships in extinct and extant animals (Rensberger 2000). 
While these issues have attracted much attention in studies of humans and other primates, they remain relatively unexplored in other vertebrates, in particular in marine mammals. Investigations focusing on pathology in cetacean teeth are still rare and underrepresented in the literature, despite being well documented for other mammalian orders, especially those animals that are domesticated or economically important (e.g. Vilà et al. 1993, Verstraete et al. 1996a,b, Wenker et al. 1999, Kene \& Uwagie-Ero 2001, Sone et al. 2004, 2005). Moreover, for cetaceans, most of the literature has focused on anomalies in the syncranium and in the axial and appendicular skeleton (Kompanje 1999, Van Bressem et al. 2006, 2007).

In Delphinidae, early studies were directed at caries in the teeth of Inia geoffrensis from Amazonian waters (Ness 1966, Pilleri \& Gihr 1969), dental anomalies in Tursiops truncatus from the coast of Florida (Brooks \& Anderson 1998), and also the use of teeth in age estimation (e.g. Hohn 1990, Myrick 1991).

A large body of evidence drawn from human and domestic animal literature has demonstrated the range of developmental and pathological conditions that may affect the dentition, including disturbances in the number, size and structure of teeth on the one hand, and bacterial and non-bacterial tooth loss on the other (for review see Hillson 1996). The main causes of these conditions may be related to endogenous or systemic factors, such as infections and nutritional deficiencies (Brooks \& Anderson 1998), or to exogenous agents, such as fermentation by bacteria, mineral deposition and acidic corrosion (Glickman \& Carranza 1992).

Dental health status is of major importance for the general well-being of animals (Wenker et al. 1999, Glatt et al. 2008). Diagnosis of pathology in the teeth of mammals is an important source of information on the generation and causes of dental anomalies (Hoff \& Hoff 1996). A comparative study in several species can provide additional information on the aetiology and pathogenicity of these abnormal conditions in animals (Sone et al. 2004). In the present study, we characterise and evaluate the occurrence of dental pathology in several extant Dephinidae species from the southern coast of Brazil.

\section{MATERIALS AND METHODS}

Material. Teeth and skulls of 9 species of 348 Delphinidae specimens were analyzed for the identification of pathological conditions. Specimens were accessed in 5 scientific collections from southern Brazil: Instituto de Pesquisas Cananéia (IPeC), Museu de Ciências Naturais UFPR (MCN), Departamento de Ecologia e Zoologia UFSC (UFSC), Museu Oceanográ- fico de Rio Grande (MORG), and Grupo de Estudos de Mamíferos Aquáticos do Rio Grande do Sul (GEMARS). Osteological material deposited in these collections came from stranded or accidentally entangled animals, normally processed by water maceration or buried in sand. Material in poor condition of preservation was not analyzed.

Diagnosis and morphological description. Identification of dental pathology was performed through macroscopic evaluation of teeth under a stereoscopic microscope. A probe for dental exploration was used to infer associated conditions such as adherent material, softening of tissues, surface texture, etc. Diagnosis was based on Ness (1966), Ortner \& Putschar (1981), Hoff \& Hoff (1996), Verstraete et al. (1996a,b), Brooks \& Anderson (1998) and Hillson (2005) (Table 1).

Lesions and anomalies were qualitatively described according to macroscopic characteristics and positioning on the tooth surface, in accordance with the anatomical terminology proposed by Smith \& Dodson (2003). When appropriate, measurements were taken with a sliding calliper $(0.05 \mathrm{~mm})$ to better characterize the abnormalities. In order to differentiate cases of erosion and wear caused by attrition and abrasion, scanning electron microscope (SEM) images of eroded tooth surfaces were taken in a JEOL JSM-6700F field emission SEM, operating at $2.5 \mathrm{kV}$ and $10 \mu \mathrm{A}$.

Upper and lower jaw alveoli were also examined, and morphological or pathological abnormalities such as margin reductions, destruction of alveolar septa and obliterations were described. Cases of bone anomalies and dental lesions in the same specimen were recorded and quantified, in order to infer the influence of dental pathology in the structure and integrity of alveolar bones.

\section{RESULTS}

A total of 27559 teeth from 348 specimens were analysed. Forty-five percent of the animals $(n=158)$ presented with some kind of dental lesion in their dentition. In $11 \%$ of cases $(n=38)$, more than one kind of pathology was observed in the same specimen. Cases of dental wear due to attrition and abrasion, which are related to occlusal anomalies, were not analysed in this study.

\section{Dental pathology}

Caries-like lesions (CLL)

Caries-like lesions (CLL) (Fig. 1A) were diagnosed in 6 species of Delphinidae (Table 2). In the 2 species of Stenella ( $S$. frontalis and $S$. coeruleoalba) these lesions 
Table 1. Descriptive diagnosis of dental pathology in Delphinids

\begin{tabular}{|c|c|}
\hline Pathology & Description \\
\hline Caries-like lesions (CLL) & $\begin{array}{l}\text { Cavity formed by destructive processes in the coronal region of teeth, resembling a funnel. } \\
\text { Chronic lesions may present yellowish or darkish coloration due to dentine sclerosis. }\end{array}$ \\
\hline Dental calculus & $\begin{array}{l}\text { Adherent substance firmly attached to the tooth surface, whose colour may vary from yellow } \\
\text { to black. }\end{array}$ \\
\hline Erosion & $\begin{array}{l}\text { Chemical destruction of dental hard tissues, resulting in shallow defects in the smooth surface } \\
\text { of the coronal enamel and/or cupping of the dentine. }\end{array}$ \\
\hline Enamel hypoplasia & $\begin{array}{l}\text { Deviations from normal shape and hardness of enamel covering in its various degrees of } \\
\text { absence, including pits, horizontal lines, grooves or missing areas of enamel. A small } \\
\text { number of teeth or the whole dentition may be affected. }\end{array}$ \\
\hline Exogenous pigmentation & $\begin{array}{l}\text { Abnormal exogenous pigmentation of enamel varying from light brown to black. Isolated } \\
\text { stains can be formed, or the whole crown may be pigmented. }\end{array}$ \\
\hline Root resorption & $\begin{array}{l}\text { Defects of the root structure, volume and shape. Resorption zones show irregular margins and } \\
\text { different degrees of resorption intensity. Lesions can be unitary or multiple. }\end{array}$ \\
\hline Shape abnormalities & $\begin{array}{l}\text { Deviation of the normal shape of teeth, including extreme variations in length and width, } \\
\text { thickness, crown curvature, root characteristics, etc. }\end{array}$ \\
\hline Geminated teeth & $\begin{array}{l}\text { Teeth with bifid crowns and a single root, whose diameter is larger than other teeth. The } 2 \\
\text { crown elements are separated by a groove, which splits the } 2 \text { teeth in some cases. }\end{array}$ \\
\hline
\end{tabular}
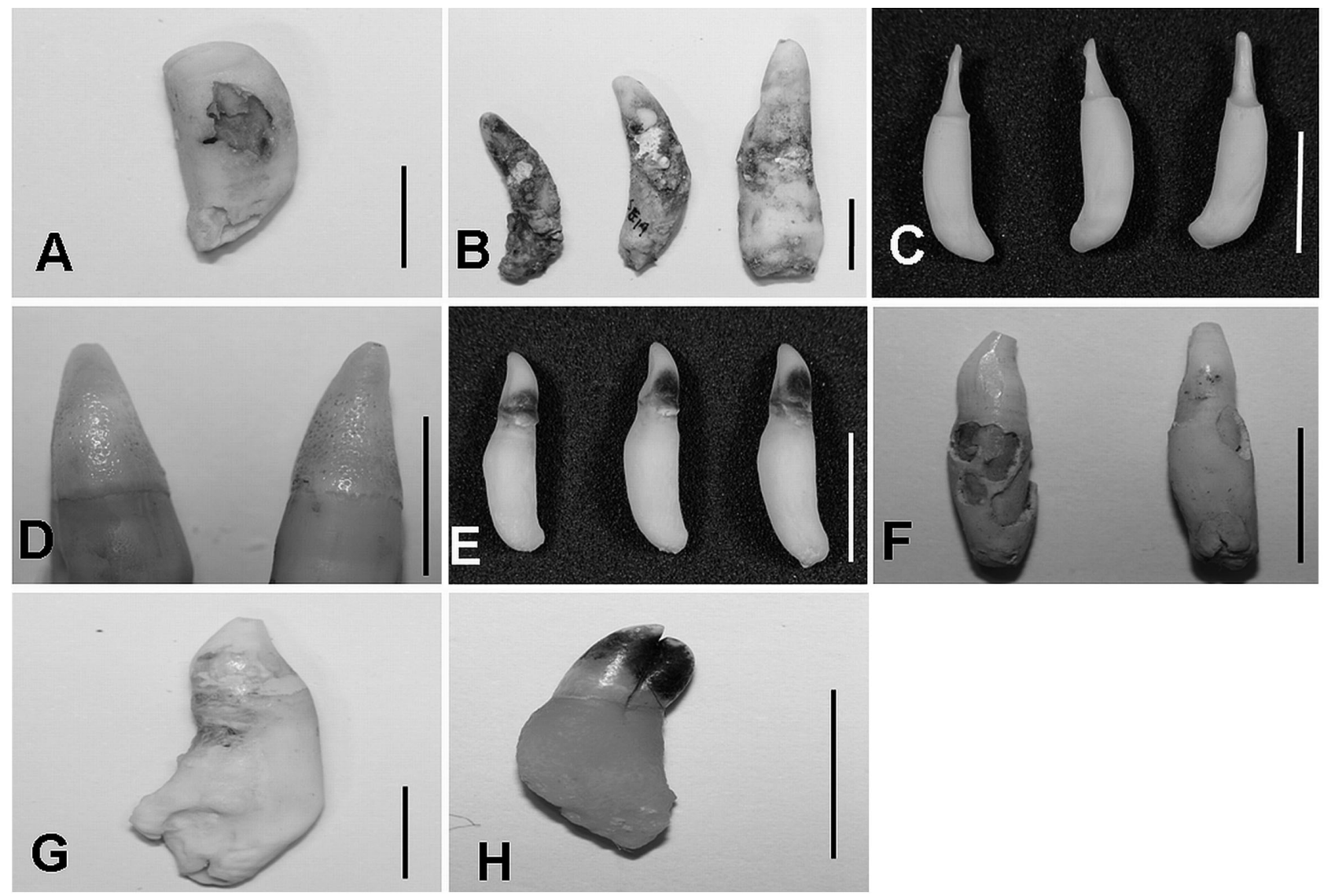

Fig. 1. Dental pathology in dolphins. (A) Tursiops truncatus. Caries-like lesion in the lateral side of the root (UFSC 1323). (B) T. truncatus. Calculus deposits (UFSC 1317). (C) Sotalia guianensis. Alteration of the crown morphology due to erosion (MCN 301). (D) T. truncatus. Amelogenesis imperfecta, a depositional enamel defect (UFSC 1045). (E) S. guianensis. Exogenous pigmentation combined with calculus deposits (MCN 180). (F) S. guianensis. Root resorption (MCN 145). (G) T. truncatus. Shape anomaly on the root (MORG 0144). (H) S. guianensis. Geminated tooth in lingual view (UFSC 1208). Scale bars $=1 \mathrm{~cm}$ 
Table 2. Incidence of dental pathology (see Table 1 for descriptions) in Delphinidae. CLL: caries-like lesions; DC: dental calculus; Er: erosion; EH: enamel hypoplasia; EP: exogenous pigmentation; RR: root resorption; SA: shape anomalies; GT: geminated teeth. $\mathrm{N}$ : total specimens examined; $\mathrm{n}(\%)$ : number of specimens (\% of total) exhibiting pathology; -: pathology not observed

\begin{tabular}{|c|c|c|c|c|c|c|c|c|c|}
\hline Species & $\mathrm{N}$ & $\begin{array}{c}\text { CLL } \\
\text { n (\%) }\end{array}$ & $\begin{array}{c}\mathrm{DC} \\
\mathrm{n}(\%)\end{array}$ & $\begin{array}{c}\text { Er } \\
\mathrm{n}(\%)\end{array}$ & $\begin{array}{c}\mathrm{EH} \\
\mathrm{n}(\%)\end{array}$ & $\begin{array}{c}\text { EP } \\
n(\%)\end{array}$ & $\begin{array}{c}\mathrm{RR} \\
\mathrm{n}(\%)\end{array}$ & $\begin{array}{c}\text { SA } \\
\mathrm{n}(\%)\end{array}$ & $\begin{array}{c}\text { GT } \\
\mathrm{n}(\%)\end{array}$ \\
\hline Delphinus capensis (common dolphin) & 18 & $1(6)$ & - & - & - & - & $1(6)$ & - & $1(6)$ \\
\hline Lagenodelphis hosei (Fraser's dolphin) & 9 & - & - & - & - & $1(11)$ & - & - & - \\
\hline Orcinus orca (killer whale) & 3 & - & $3(100)$ & $1(33)$ & - & - & - & - & - \\
\hline Pseudorca crassidens (false killer whale) & 4 & - & $4(100)$ & $1(25)$ & - & - & - & - & - \\
\hline Sotalia guianensis (estuarine dolphin) & 205 & $4(2)$ & $15(7)$ & $10(5)$ & - & $53(26)$ & $27(13)$ & - & $17(8$ \\
\hline Stenella coeruleoalba (striped dolphin) & 8 & $2(25)$ & - & - & - & $2(25)$ & - & - & $1(12)$ \\
\hline Stenella frontalis (Atlantic spotted dolphin) & 23 & $7(30)$ & - & - & $1(4)$ & $5(22)$ & $2(8)$ & - & - \\
\hline Steno bredanensis (rough-toothed dolphin) & 17 & $1(6)$ & $1(6)$ & $4(24)$ & $1(6)$ & $1(6)$ & - & - & - \\
\hline Tursiops truncatus (bottlenose dolphin) & 61 & $2(3)$ & $4(7)$ & $2(3)$ & $9(15)$ & $13(21)$ & $12(20)$ & $8(13)$ & $1(2)$ \\
\hline
\end{tabular}

were relatively important and occurred more frequently on the neck and root, with the greatest depths reaching $1.5 \mathrm{~mm}$. Root CLLs occurred in fractured areas of the teeth, where cavities of dark colour were observed.

Sotalia guianensis and Delphinus capensis had lesions with irregular shape, resembling oval or rounded forms. Lesions measured from 1 to $2 \mathrm{~mm}$ in diameter and were a maximum of 1 to $2 \mathrm{~mm}$ in depth. Root CLLs compromising the entire tooth diameter were observed only in Steno bredanensis. In Tursiops truncatus, lesions were observed in the root region and also on the crown. While root CLLs were cavities of irregular shape and a greater depth of 2 to $5 \mathrm{~mm}$, with both external margins and the internal region showing dark colour due to sclerosis of dentinal tissues, coronal lesions were lighter in colour and were diagnosed in the margins of lateral wear, presenting with variable depth and size.

\section{Dental calculus}

Dental calculus (Fig. 1B) was diagnosed in 5 delphinids (Table 2). Where calculus was observed in Sotalia guianensis and Steno bredanensis, it appeared to be mostly concentrated around the necks of the teeth, often forming a ring-like deposit that was thicker on the buccal side. The colours varied from yellowish grey to black, with conspicuous deposits presenting with a darker colour. Often, calculus appeared to be associated with exogenous pigmentation of the tooth crown.

In Tursiops truncatus, most commonly calculus deposits formed a ring involving the neck and root of the teeth, but calculus was observed in fractured areas as well. In a particular case (UFSC 1317), calculus affected almost the whole dentition. This single specimen presented with $59 \%(\mathrm{n}=43)$ of its teeth having conspicuous calculus deposits. In Orcinus orca and
Pseudorca crassidens, calculus deposits were similarly concentrated on the tooth neck, forming a belt around the cervical region. Calculus incidence was registered in all specimens analyzed from these 2 species (Table 2). The colour of the deposits also varied from light grey to black, and darker coloration was observed in conspicuous deposits.

\section{Erosion}

Erosion (Fig. 1C) was recorded in 5 Delphinidae species (Table 2). In Sotalia guianensis, different stages of erosion were observed, such as small loss of dentine on the tooth cervix resulting in narrowing and other morphological variations (mild erosion), to partial or full destruction of the coronal region (severe). In all cases, we observed the loss of the normal outlines of the teeth and the presence of concavities with a glassy appearance, as if the teeth had been polished. SEM images of eroded surfaces showed a rough denaturated surface consistent with acid etching, which lacks the tramlining grooves characteristic of attrition (Fig. 2).

Commonly the lingual side of teeth was more affected by erosion. More severe cases involved exposure of the pulp cavity both in specimens with obliterated or patent pulp cavities. Cases of erosion in Tursiops truncatus were diagnosed on the cervical region in mild or moderate stages, resulting in thinning of the cervix.

In Pseudorca crassidens, there was narrowing of the cervical region and the formation of cavities with a glassy appearance. Orcinus orca presented with lesions restricted to the enamel, compromising only the superficial layers of dentine. Effects were more marked on the lingual side of the teeth, but they were also observed on the buccal side in some cases. In Steno bredanensis, enamel and dentine losses were diagnosed mainly in the tooth neck on the lingual side, 


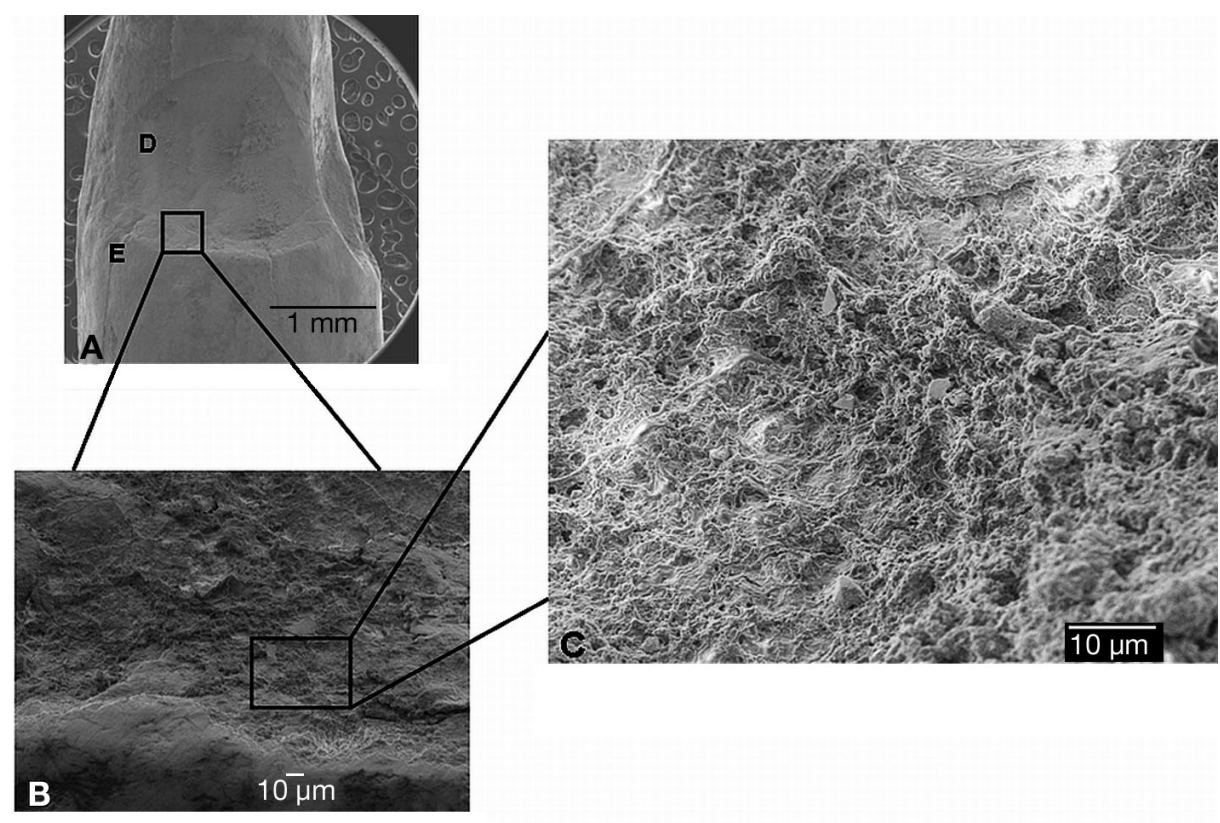

Fig. 2. Sotalia guianensis (MCN 060). (A) Low power (27×) scanning electron microscopy of the eroded tooth, showing enamel (E) and dentine (D). (B) Higherpower view $(400 \times)$ of the enamel-dentinal junction showing smooth wear of denaturated enamel and dentine. (C) High-power view $(1500 \times)$ of eroded dentine showing a rough denaturated surface, which lacks the tramlining grooves characteristic of attrition in the form of thinning and unusual constrictions. In some specimens, minimal traces of enamel covering were still observed above the tooth cervix and in the crown apex.

\section{Enamel hypoplasia}

Enamel hypoplasia (Fig. 1D) was diagnosed in Tursiops truncatus, Stenella frontalis and Steno bredanensis (Table 2). In these 3 species, zones of hypoplasia were diagnosed as roughly rounded regions where the enamel was absent. In most cases, areas of enamel hypoplasia were seen on the buccal side of the middle third of the tooth crown. Although in some specimens of $T$. truncatus more than one tooth presented with hypoplasia, in most of the other cases only one tooth was affected. However, in the specimen UFSC 1045, all the teeth presented with small pits and concavities in the enamel covering, giving an irregular aspect to the tooth surface. The enamel was opaque and rough in contrast to the glassy pattern normally observed.

\section{Exogenous pigmentation}

Exogenous pigmentation (Fig. 1E) was recorded in 6 species (Table 2). Exogenous pigmentation ranged from light yellow and grey to darker tones such as brown and black. Often these pigmented teeth also showed isolated, less-conspicuous stains, but some specimens presented with the whole crown stained in black. In some cases the darker pigmentation occurs associated with calculus deposits. The buccal side was generally more heavily pigmented, with stains on the lingual side observed less frequently.

\section{Root resorption}

Root resorption (Fig. 1F) was diagnosed in Sotalia guianensis, Delphinus capensis, Tursiops truncatus and Stenella frontalis (Table 2) and was found on the 4 surfaces of the root or in the root apex. Apical root resorption was often associated with accessory rootlike projections with the appearance of dentine and/or cement.

Resorbed areas showed undefined shapes and irregular margins, most frequently affecting the root apex. However, in severe cases larger parts of the root were damaged. In Tursiops truncatus some cases of root apex resorption were also associated with crown and root fractures. Root resorption on the root surfaces commonly presented with an oval shape, irregular margins, and little depth. The extension of the losses occupied a restricted area of the root, but often a wider area was affected, compromising the root volume and structure.

\section{Shape anomalies}

Shape anomalies (Fig. 1G) were diagnosed only in Tursiops truncatus (Table 2). Most shape anomalies were related to the flattening and thinning of the tooth cervix and root, which was uncharacteristic of the 
usual morphology of these regions. It is important to note that these modifications were not caused by conditions that may also change the normal shape of the teeth (such as dental erosion, for example) and were related to developmental processes. Shape anomalies were also related to modifications in the root shape that included anomalous increments of dentine and unusual root curvatures.

\section{Geminated teeth}

Geminated teeth (Fig. 1H) were recorded in 4 species (Table 2). These cases were diagnosed by the presence of a longitudinal fissure on the lingual and buccal sides between the 2 crown elements. In some cases, these fissures reached the tooth neck and the 2 elements were completely split; in other cases the fissure was incomplete. Usually, these 2 elements were not symmetrical and have distinct size differences. While the root diameter was larger in geminated teeth, the pulp cavity was single.

\section{Alveolar abnormalities}

Of the 105 skulls that presented with alveolar lesions, $37 \%(n=39)$ of the specimens also presented dental pathology. On the other hand, $46 \%(n=48)$ of the specimens had no sign of related dental pathology. The remaining $17 \%$ of the skulls did not have teeth stored in the scientific collections.

Cases of marginal reduction, obliteration, remodelling or destruction of dental alveoli, and other bony changes consistent with periodontal disease, were ob- served in specimens with calculus, caries-like lesions and root resorption (Fig. 3A). In some cases, we also observed the increasing roughness of alveoli, presence of extra bony tissue on margins of mandible or maxilla, or even lytic and inflammatory bone lesions, such as osteomyelitis. In severely affected skulls, no differentiation between post or ante-mortem tooth loss was possible (Fig. 3B).

\section{DISCUSSION}

That the aetiology of dental caries and other commonly observed dental pathology in humans is complex and multifactorial is not novel, and has been accompanied by a significant broadening of our understanding of tooth formation, eruption and wear. However, a less explored area is the prevalence of these conditions in wild animals, particularly those that are not commercially valuable (e.g. Wenker et al. 1999, Glatt et al. 2008). Although many animal models have been used to improve the understanding of the aetiology of dental diseases in humans, the processes involved are never identical among species (Miles \& Grigson 1990). As dental pathology often reflects the influence of diet and microorganisms that inhabit the buccal flora, it seems likely that there should be different aetiologies for species that have teeth with different morphologies, who use their teeth differently, and who occupy the marine environment with its unique and inherent ecological challenges.

Dental caries is the result of a process of dental tissue destruction thought to be caused by fermentation of free carbohydrates by bacteria, mainly Streptococcus mutans. This process starts at the enamel level and
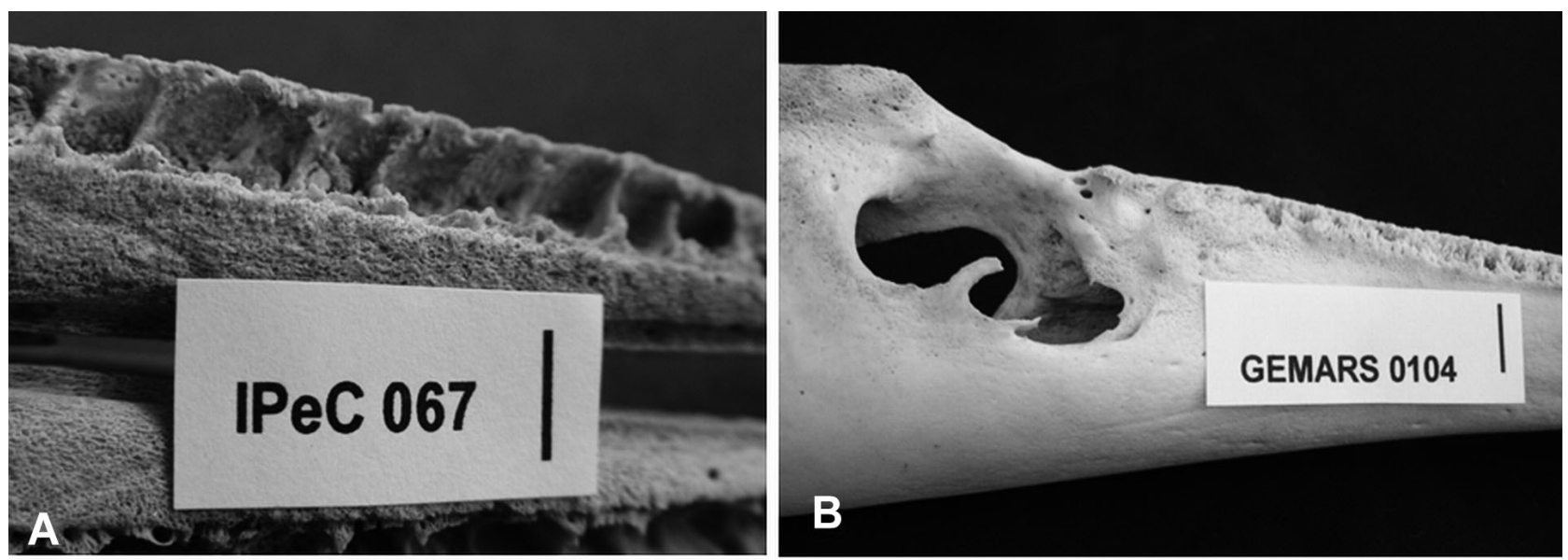

Fig. 3. (A) Sotalia guianensis. Marginal reduction and destruction of maxillary alveoli consistent with periodontal disease associated to dental pathology. (B) Delphinus capensis. Osteomyelitis in the right mandible, with alveoli damaged or obliterated. See 'Materials and methods: Material' for scientific collection names in full. Scale bars $=1 \mathrm{~cm}$ 
penetrates into the dentine, where bacterial acids provoke decalcification, softening and loss of dentinal tissues (Hillson 2005). While it is common among humans and domestic animals, dental caries has also been documented in wild species, such as chiropterans, carnivores, rodents and primates (Miles \& Grigson 1990, Sone et al. 2005).

In cetaceans, the occurrence of dental caries was reported for Inia geoffrensis (Ness 1966, Pilleri \& Gihr 1969, Silva 1995) and Tursiops truncatus (Brooks \& Anderson 1998). Records from Ness (1966) and Pilleri \& Gihr (1969) on Amazonian dolphins were later contested due to the lack of evidence of a carbohydrate source in their diet and the absence of true softening of dentinal tissues, thought to be a fundamental condition for the development of dental caries (Miles \& Grigson 1990). Ness (1966) mentioned that the association between diets rich in carbohydrates and the occurrence of dental caries is strong in humans but less plausible in piscivorous or teuthophagous cetaceans. Waters of the Amazon basin are rich in organic nutrients, although it is less plausible that they were responsible for dental caries in I. geoffrensis.

Miles \& Grigson (1990) suggested the adoption of the term 'caries-like' to refer to the destructive lesions of unknown origin that resemble human dental caries. They also noted that the use of the term 'caries' should be adopted with prudence only in specimens submitted to confirmative histological analysis. According to these recommendations, we adopted the term 'carieslike lesions' (CLL) for the present study.

In our study, CLLs were registered in Stenella frontalis, Stenella coeruleoalba, Delphinus capensis, Steno bredanensis, Tursiops truncatus and Sotalia guianensis. Although root CLLs are rare in other mammals, they appear to be more common in dolphins. On the other hand, coronal CLLs were rare and were registered only in Stenella frontalis and T. truncatus. Root caries occurs both in humans and other animals due to periodontal attachment loss and root exposure (Ortner \& Putschar 1981, Miles \& Grigson 1990) with subsequent bacterial plaque accumulation responsible for the destructive processes observed. Another possible factor that could facilitate root caries is excessive wear and fractures, which could expose dentine to the accumulation of food particles and bacterial colonization (Hillson 2005).

Dental calculus is formed due to the mineralization of dental plaque, with plaque fluids and saliva being the main mineral sources of these deposits (Hillson 2005). According to Roberts-Harry \& Clerehugh (2000), $80 \%$ of calculus is comprised of inorganic salts, with the remaining content of an organic matrix of protein, lipids and carbohydrates.

The present study showed mineral deposits in Sotalia guianensis, Steno bredanensis, Tursiops trun- catus, Pseudorca crassidens and Orcinus orca. Even though the sample sizes are relatively small, we should point out that all specimens of $P$. crassidens and O. orca presented this pathology. Although we cannot discharge the individual effect that could have biased the sample, this could be an indication that this pathology is common among Globicephalinae (sensu Perrin 1989).

The extent and coloration of calculus were similar to those of supragingival deposits described in other mammal orders: yellowish-to-black colour and localized mainly on the lingual or buccal surfaces (Miles \& Grigson 1990, Hillson 2005). On the other hand, subgingival calculus deposits occurred when there was root exposure due to periodontal disease. These deposits tend to form a ring around the root and present with a darker colour due to the presence of blood and other gingival fluids (Roberts-Harry \& Clerehugh 2000, Hillson 2005). Silva (1995) mentioned the occurrence of calculus rings under the gum line in Inia geoffrensis, but did not offer more information about this pathology.

The formation of bacterial plaque normally precedes the mineralization of deposits (Ortner \& Putschar 1981, Roberts-Harry \& Clerehugh 2000), but little is known about the occurrence and structure of dental plaque in delphinids. Goldman et al. (2002) analyzed dental plaque in teeth of Tursiops gephyreus and detected bacteria diagnosed in cases of gastritis, but they did not furnish details about the nature and localization of these deposits. Another question that deserves further investigation is the source of minerals: saliva and plaque fluids furnish minerals for dental calculus in humans and domestic animals (Lieverse 1999, Hillson 2005), but we do not know how these deposits are formed in cetaceans. Salivary ducts were observed in histological studies of tongues (Guimarães 2006), but unfortunately little is known about the amount of saliva secreted or its composition. Marine salts could influence the process of calculus formation by increasing mineral availability (Lieverse 1999), but this hypothesis needs further confirmation.

Diets rich in protein contribute to calculus formation by increasing the alkalinity in the oral cavity and facilitating mineral precipitation (Lieverse 1999). This observation is consistent with the occurrence of calculus in delphinids, because of the composition of their diet (fish, squid, crustaceans, and also other marine mammals in some killer whale pods; Baird 2000). However, calculus is not commonly observed in wild animal species (Clarke \& Cameron 1998, Hillson 2005). Domestic or zoo animals present with higher rates of dental calculus than wild animals, possibly because they are fed an improperly textured diet (Wenker et al. 1999, Sone et al. 2004, Hillson 2005). 
Dental erosion involves the loss of dental structure through a chemical process without the action of bacteria. Due to a reduced intra-oral $\mathrm{pH}$, the enamel and dentine are demineralised, resulting in softening of the dental surface and lower resistance to wear (Nunn 1996, Litonjua et al. 2003). The origins of erosion are multifactorial and can be related to disorders of the gastroesophageal tract, diets rich in acidic substances and action of environmental acids on the dental tissues (Cardoso \& Grando 2003).

Dental erosion, diagnosed as cupping of the dentine (Bell et al. 1998), was recorded in delphinids for the first time by the present study. Cases were diagnosed in Sotalia guianensis, Tursiops truncatus, Steno bredanensis, Orcinus orca and Pseudorca crassidens. Records of the distinct intensity of dental erosion in Sotalia guianensis, from small losses of enamel and dentine to the complete disappearance of the entire dental crown, suggest that this process is progressive and cumulative. The higher incidence of dental erosion on the lingual surfaces suggests the operation of intrinsic factors, as observed in humans with disturbances of the gastrooesophageal tract (Cardoso \& Grando 2003).

Interestingly, Kieser et al. (2001) reported erosive patterns in the early Maori of New Zealand, and attributed these to marine dependence. It was argued that there is usually not a single process involved in toothwear, rather, all 3 forms probably operate, with different processes dominating at different times during the life cycle. Hence, while sand ingestion probably played an important role in initial abrasion of the teeth, dentinal loss with cupping beneath the enamel observed in delphinids is probably due to erosion alone. Although we also cannot discount the influence of the acidity of the diet and free acids in the aquatic environment on the occurrence of these cases, the regurgitation of gastric secretions seems to be a plausible explanation for the observed cases of dental erosion.

Enamel abnormalities consist of depositional anomalies and exogenous pigmentation. Abnormalities that imply depositional defects are known as enamel hypoplasia and may be related to nutritional deficiencies, systemic infections, trauma, and local infections. Their effects may be restricted to a few teeth or to specific areas of a given tooth crown (Miles \& Grigson 1990). On the other hand, amelogenesis imperfecta is an ameloblast dysfunction that implies irregular enamel covering in the whole dentition. Different from enamel hypoplasia, amelogenesis is caused by a genetic mutation and is considered an inherited defect (Kim et al. 2006).

We identified enamel hypoplasia in Stenella frontalis, Steno bredanensis and Tursiops truncatus. All cases were restricted to 1 or 2 teeth in specific parts of the tooth crown, with the exception of the specimen UFSC 1045 (T. truncatus), whose appearance suggested amelogenesis imperfecta. Crown irregularities in this specimen were observed in all teeth and consisted of pinhead sized pits that were spread across the tooth surface, alternating with areas of normal enamel (Neville et al. 2002). Brooks \& Anderson (1998) described a case of amelogenesis imperfecta in T. truncatus, but the absence of enamel covering combined with dentine loss lead us to believe that it was possibly a case of dental erosion that was mistakenly identified as an abnormality of enamel deposition.

Enamel anomalies may also involve exogenous pigmentation in the crown. According to Glickman \& Carranza (1992), this results from the development and adhesion of food items and bacterial plaque, usually from chromogenic bacteria. Food items that have pigmentational potential can also produce darker coloration to the tooth crown (Neville et al. 2002). In southern Brazilian delphinids, we recorded exogenous pigmentation in 7 species (Table 2). Isolated yellow or brown stains are common on the buccal side, although in some cases the entire crown is pigmented with black stains.

Dental abnormalities can also be found in other tooth regions not exposed to the external environment, such as tooth roots. Root resorptions were recorded in Sotalia guianensis, Stenella frontalis, Delphinus capensis and Tursiops truncatus and were, in some cases, associated with accessory root-like projections. External root resorption may result from the action of the cells of the periodontal ligament in response to inflammation, trauma and excessive occlusal forces (Neville et al. 2002). Miles \& Grigson (1990) described cases of dental resorption in odontocetes as limited to one side of the root, and they associated this occurrence with occlusal stress. This stress could lead to inflammation of marginal tissues and stimulate the resorption of certain radicular zones. The observation of wear facets in specimens with root resorption in this study is consistent with the hypothesis of resorption due to contact stress. It is interesting to observe that cases of root resorption were relatively important in T. truncatus, a species that frequently shows threatening behaviours that involve clapping (Östman 1991).

Brooks \& Anderson (1998) recorded the occurrence of accessory root-like projections on the root apex in 2 specimens of Tursiops truncatus, apparently similar to what was observed in some species in the present study. The projections observed in $T$. truncatus had incremental lines, but those authors could not determine if these zones were composed by dentine, cement, or a combination of these 2 elements.

In relation to morphological anomalies, cases of gemination and shape anomalies were also observed. 
Geminated teeth originate from an incomplete division of the dental follicle in 2 teeth, resulting in a tooth with a double crown but a single root (Schuurs \& van Loveren 2000, Kompanje 2001). We observed gemination of dental elements in Stenella coeruleoalba, Delphinus capensis, Sotalia guianensis and Tursiops truncatus. This condition had been previously described in other cetacean species (e.g. Phocoena phocoena, D. capensis, Physeter macrocephalus, Inia geoffrensis: Miles \& Grigson 1994; Pontoporia blainvillei: Pinedo 1991, Heras et al. $1994 ;$ S. guianensis: Simões-Lopes 2006; T. truncatus: Kompanje 2001). Heras et al. (1994) and Pinedo (1991) speculated that the prevalence of geminate teeth was higher in the caudal dentition of both jaws, but the evaluation of single teeth out of the dental row did not allow us to make these inferences.

Shape abnormalities involve abnormalities in the crown shape, root diameter, abnormal thinning, accessory cusps and other modifications in tooth structure. They are relatively common in some mammals (Hoff \& Hoff 1996). These anomalies were diagnosed only in Tursiops truncatus and were restricted to abnormal narrowing and unusual root curvatures. According to Neville et al. (2002), trauma suffered during dental development may lead to the occurrence of these anomalies. Aggressive behaviour and collisions among individuals are not rare in T. truncatus (Östman 1991) and may explain the occurrence of these anomalies in this species.

Alveolar abnormalities were found in $37 \%$ of the specimens with dental pathology, suggesting that there is an association with pathological condition in teeth and in the bony tissue. It is known that chronic periodontal disease may result in the loss of periodontal bony tissue, causing reduction of alveolar margins and resorption of interalveolar septa (De Smet 1977, Miles \& Grigson 1990). Excessive wear combined with root caries may also lead to inflammatory processes and damage to the bony tissue that can cause periodontal disease. According to Miles \& Grigson (1990), this is the most common mechanism of loss of bony tissue diagnosed in wild animals.

A reduction of the alveolar margin is common with the progression of age and should be taken into consideration in the diagnosis of cases generated by pathological conditions. While this reduction affects the whole circumference of the tooth and is observed in most of the teeth, cases related to periodontal disease show alveolar walls being heterogeneously affected, making them irregular and more wrinkled (Miles \& Grigson 1990). Of course, reduction could be result of iatrogenic processes such as cleaning and preparation of skulls, which can also generate bone tissue loss.

Alveolar destruction and the presence of large lytic lesions can lead to loss of teeth (De Smet 1977,
Robineau 1981, Van Bressem et al. 2007), which can be related to the cases where teeth were absent in skulls with severe bone pathology. This leads us to believe that in chronic and progressive stages of dental diseases, these can generate anomalies in maxillary and mandibular bones and add to the burden of morbidity of affected animals. Of course, the obverse is also true. In other words, bone pathology per se can also lead to dental pathology and tooth loss, for example in cases of traumatic fractures (De Smet 1977, Montes et al. 2004, Van Bressem et al. 2006, 2007), osteolytic lesions and osteomyelitis of cranial bones (Montes et al. 2004, Van Bressem et al. 2006, 2007).

Acknowledgements. Thanks are extended to the curators of the scientific collections (Dr. E. Monteiro-Filho at IPeC/PR; Dr. F. Sedor at MCN/PR; Dr. I. Moreno at GEMARS/RS; and Dr. E. Secchi at MORG/RS) for allowing us to assess the specimens under their care. Two anonymous referees provided valuable comments that greatly improved this manuscript, and R. E. Fordyce kindly proofread the final version. L. Girvan (Department of Anatomy \& Structural Biology, University of Otago, New Zealand) helped with SEM facilities. C.L. acknowledges Conselho Nacional de Desenvolvimento Científico e Tecnológico (CNPq) for a MSc scholarship (process number 132356/2007-4) and Programa de Pós-graduação em Ciências Biológicas-Zoologia/UFPR for institutional support. P.C.S-L. acknowledges a CNPq grant (process number 304698/2006-7).

\section{LITERATURE CITED}

Baird RW (2000) The killer whale: foraging behavior and group hunting. In: Mann J, Connor RC, Tyack PL, Whitehead $\mathrm{H}$ (eds) Cetacean societies: field studies of dolphins and whales. University of Chicago Press, Chicago, IL, p 127-153

Bell EJ, Kaidonis J, Townsend G, Richards L (1998) Comparison of exposed dentinal surfaces resulting from abrasion and erosion. Aust Dent J 43:362-366

Bergqvist LP (2003) The role of teeth in mammal history. Braz J Oral Sci 2:249-257

Brooks L, Anderson HF (1998) Dental anomalies in bottlenose dolphins, Tursiops truncatus, from the west coast of Florida. Mar Mamm Sci 14:849-853

Cardoso AC, Grando LJ (2003) Bruxismo X erosão de esmalte e dentina. In: Cardoso AC (ed) Oclusão: para você e para mim. Santos Livraria e Editora, São Paulo, p 60-113

> Clarke DE, Cameron A (1998) Relationship between diet, dental calculus and periodontal disease in domestic and feral cats in Australia. Aust Vet J 76:690-693

De Smet WMA (1977) The fate of old bottle-nosed dolphins, Tursiops truncatus, in nature as revealed by the condition of their skeletons. Aquat Mamm 5:78-86

Glatt SE, Francl KE, Scheels JL (2008) A survey of current dental problems and treatments of zoo animals. Int $\mathrm{Zoo} \mathrm{Yb}$ 42:206-213

Glickman I, Carranza FA (1992) Periodontia clínica. Guanabara Koogan, Rio de Janeiro

Goldman CG, Loureiro JD, Quse V, Corach D and others (2002) Evidence of Helicobactersp. in dental plaque of captive dolphins (Tursiops gephyreus). J Wildl Dis 38:644-648 
Guimarães JP (2006) Análise morfológica da superfície de interface epitélio-tecido conjuntivo da face dorsal da língua de cetáceos (ordem Cetacea, subordem Odontoceti), empregando os métodos de microscopia de luz e eletrônica de varredura. MSc Thesis, Universidade de São Paulo, São Paulo

Heras MP, Junín M, Castello HP (1994) Morfologia dental en Pontoporia blainvillei (Gervais \& D'Orbigny, 1844). In: Oporto J (ed) $4^{\mathrm{a}}$ Reunion de trabajo de especialistas en mamíferos acuáticos de America del Sur, Valdívia, 12-15 Nov 1990. CIMMA-Chile, Valdívia, p 171-175

Hillson S (1996) Dental anthropology. Cambridge University Press, Cambridge

Hillson S (2005) Teeth. Cambridge manuals in archaeology. Cambridge University Press, Cambridge

Hoff GL, Hoff DM (1996) Dental anomalies in mammals. In: Fairbrother A, Locke LN, Hoff GL (eds) Noninfectious diseases of wildlife. Iowa State University Press, IA, p 100-108

Hohn A (1990) Reading between the lines: analysis of age estimation in dolphins. In: Leatherwood S, Reeves R (eds) The bottlenose dolphin. Academic Press, San Diego, CA, p 575-585

Kene ROC, Uwagie-Ero EA (2001) Dental abnormalities of nomadic cattle of Nigeria. Trop Vet 19:191-199

Kieser JA, Dennison JK, Kaidonis JA, Huang D, Herbison PGP, Tayles NG (2001) Patterns of dental wear in the early Maori dentition. Int J Osteoarchaeol 11:206-217

Kim JW, Simmer JP, Lin BPL, Seymen F, Bartlett JD, Hu JCC (2006) Mutational analysis of candidate genes in 24 amelogenesis imperfecta families. Eur J Oral Sci 114:3-12

Kompanje EJO (1999) Considerations on the comparative pathology of the vertebrae in Mysticeti and Odontoceti; evidence for the occurrence of discarthrosis, zygarthrosis, infectious spondylitis and spondyloarthritis. Zool Med Leiden 73:99-130

Kompanje EJO (2001) Review of strandings and catches of Tursiops truncatus (Mammalia, Cetacea, Odontoceti) in the Netherlands between 1754 and 2000. Deinsea 8:169-224

Larsen CP (1997) Bioarchaeology. Cambridge University Press, Cambridge

Lieverse AR (1999) Diet and the aetiology of dental calculus. Int J Osteoarchaeol 9:219-232

Litonjua LA, Andreana DDS, Bush PJ, Cohen RE (2003) Tooth wear: attrition, erosion and abrasion. Quintessence Int 34: 435-446

Miles AEW, Grigson C (1990) Colyer's variations and diseases of the teeth of animals. Cambridge University Press, Cambridge

Montes DI, Chavera AC, Van Bressem M, Perales RC, Falcón NP, Van Waerebeek K (2004) Descripción y evaluación anatómica de lesiones óseas cráneo-mandibulares en cetáceos odontocetos del mar peruano. Rev Investig Vet Perú 15:13-24

Myrick AC Jr (1991) Some new potential uses of dental layers in studying delphinid populations. In: Pryor K, Norris KS (eds) Dolphin societies. University of California Press, Berkeley, CA, p 251-279

Ness AR (1966) Dental caries in the platanistid whale Inia geoffrensis. J Comp Pathol 76:271-279

Neville BW, Damm DD, Allen CM, Bouquot JE (2002) Patologia oral e maxilofacial. Guanabara Koogan, Rio de Janeiro

Nunn JH (1996) Prevalence of dental erosion and implications for oral health. Eur J Oral Sci 104:156-161

Ortner DJ, Putschar WGJ (1981) Identification of pathological

Editorial responsibility: Michael Moore,

Woods Hole, Massachusetts, USA conditions in human skeletal remains: lesions of jaws and teeth. Smithson Contrib Anthropol 28: 436-456

Östman J (1991) Changes in aggressive and sexual behavior between two male bottlenose dolphins (Tursiops truncatus) in a captive colony. In: Pryor K, Norris KS (eds) Dolphin societies. University of California Press, Berkeley, CA, p 305-317

Perrin WF (1989) Dolphins, porpoises and whales: an action plan for the conservation of biological diversity. International Union for the Conservation of Nature, Cambridge

Pilleri G, Gihr M (1969) Zur Anatomie und Pathologie von Inia geoffrensis de Blainville 1817 (Cetacea, Susuidae) aus dem Beni, Bolivien. Investig Cetacea 1:94-106

Pinedo MC (1991) Development and variation of the Franciscana, Pontoporia blainvillei. PhD Thesis, University of California, Santa Cruz, CA

Rensberger JM (2000) Pathways to functional differentiation in mammalian enamel. In: Teaford MF, Smith MM, Ferguson MWJ (eds) Development, function and evolution of teeth. Cambridge University Press, Cambridge, p 252-269

Roberts-Harry EA, Clerehugh V (2000) Subgingival calculus: Where are we now? A comparative review. J Dent 28: 93-102

Robineau D (1981) Sur quelques cas d'edentation partielle chez Delphinus delphis et leur signification. Aquat Mamm 8:33-39

Schuurs AHB, van Loveren C (2000) Double teeth: review of the literature. ASDC J Dent Child 67:313-325

Silva VMF (1995) Age estimation of the Amazon dolphin, Inia geoffrensis, using laminae in the teeth. Rep Inter Whal Comm (16):531-543

Simões-Lopes PC (2006) Morfologia do sincrânio de Sotalia guianensis (P.J. van Bénéden, 1864) (Cetacea: Delphinidae). Rev Bras Zool 23:652-660

Smith JB, Dodson P (2003) A proposal for a standard terminology of anatomical notation and orientation in fossil vertebrate dentitions. J Vertebr Paleontol 23:1-12

Sone K, Koyasu K, Oda S (2004) Dental and skull anomalies in the feral coypu, Myocastor coypus. Arch Oral Biol 49: 849-854

Sone K, Koyasu K, Tanaka S, Oda S (2005) Effects of diet on the incidence of dental pathology in free living caviomorph rodents. Arch Oral Biol 50:323-331

Van Bressem MF, Van Waerebeek K, Montes D, Kennedy S and others (2006) Diseases, lesions and malformations in the long-beaked common dolphin Delphinus capensis from the Southeast Pacific. Dis Aquat Org 68:149-165

Van Bressem MF, Van Waerebeek K, Reyes JC, Felix F and others (2007) A preliminary overview of skin and skeletal diseases and traumata in small cetaceans from South America waters. Lat Am J Aquat Mammal 6:7-42

- Verstraete FJM, Van Aarde RJ, Nieuwoudt BA, Mauer E, Kass PH (1996a) The dental pathology of feral cats on Marion Island. Part I. Congenital, developmental and traumatic abnormalities. J Comp Pathol 115:265-282

Verstraete FJM, Van Aarde RJ, Nieuwoudt BA, Mauer E, Kass $\mathrm{PH}$ (1996b) The dental pathology of feral cats on Marion Island. Part II. Periodontitis, resorption lesions and mandibular thickening. J Comp Pathol 115:283-297

Vilà C, Urios V, Castroviejo J (1993) Tooth losses and anomalies in the wolf (Canis lupus). Can J Zool 71:968-971

Wenker CJ, Stich H, Müller M, Lussi A (1999) A retrospective study of dental conditions of captive brown bears (Ursus arctos spp.) compared with free-ranging alaskan grizzlies (Ursus arctos horribilis). J Zoo Wildl Med 30:208-221 